JIEB (ISSN : 2442-4560) available online at : ejournal.stiepancasetia.ac.id

\title{
PENGARUH GAYA KEPEMIMPINAN KEPALA SEKOLAH, MOTIVASI KERJA DAN KOMPETENSI GURU TERHADAP KINERJA GURU SD NEGERI SE-KECAMATAN MARTAPURA BARAT KABUPATEN BANJAR
}

\author{
Nurfeny Zunia Rahmah \\ Mahasiswa Sekolah Tinggi Ilmu Ekonomi Pancasetia Banjarmasin \\ Jl. A Yani Km. 5,5 Banjarmasin, Kalimantan Selatan \\ e-mail: nurzuniaR@yahoo.co.id
}

\begin{abstract}
: the purpose of this study is to describe the influences of principles' leadership style, work motivation and competence toward performance of elementary schools teachers in West Martapura Subdistrict Banjar Regency. This research is descriptive-quantitative research. There are 57 samples which determined by using total sampling. The data collection techniques are questionnaire and documentation. The result of this research shows that leadership style, work motivation and competence affect teachers' performance. The competence variable is the dominant variable.
\end{abstract}

\section{Keywords: motivation, work discipline, work satisfaction, performance}

\begin{abstract}
Abstrak: Tujuan penelitian ini adalah untuk mendeskripsikan pengaruh gaya kepemimpinan kepala sekolah, motivasi kerja, dan kompetensi terhadap kinerja guru SD Negeri se-Kecamatan Martapura Barat Kabupaten Banjar. Jenis penelitian ini adalah penelitian kuantitatif-deskriptif. Sampel penelitian ditentukan dengan cara sampel total yaitu sebanyak 57 orang. Teknik pengumpulan data yang digunakan dalam penelitian ini adalah menggunakan angket dan dokumentasi. Hasil dari penelitian menunjukkan bahwa terdapat pengaruh gaya kepemimpinan kepala sekolah, motivasi kerja, dan kompetensi terhadap kinerja guru. Variabel kompetensi memiliki berpengaruh dominan terhadap kinerja guru.
\end{abstract}

Kata Kunci: motivasi, disiplin kerja, kepuasan kerja, kinerja

\section{Latar Belakang}

Pendidikan merupakan salah satu kebutuhan yang tidak dapat dipisahkan dari kehidupan manusia. Pendidikan merupakan sarana yang paling penting dalam pengembangan sumber daya manusia, mencerdaskan kehidupan bangsa dan membentuk manusia yang terampil di bidangnya. Sebagai lembaga pendidikan formal, sekolah merupakan tempat pengembangan ilmu pengetahuan, kecakapan, keterampilan, nilai dan sikap yang diberikan secara lengkap kepada generasi muda untuk membantu perkembangan potensi dan kemampuan agar bermanfaat bagi kepentingan hidupnya. Sekolah yang dikelola dengan baik dari segi pembelajaran dan manajemennya akan menghasilkan output yang lebih berkualitas, sedangkan sekolah yang manaje- mennya kurang baik, tidak akan memberikan kualitas dan lulusan yang baik pula. Banyak sekolah yang tidak terkelola dari segi sistem pembelajaran dan manajemennya sehingga sekolah tersebut kurang bermutu.

Keberhasilan pendidikan di sekolah salah satunya ditentukan oleh mutu guru. Guru merupakan salah satu unsur di bidang kependidikan yang harus berperan secara aktif dan menempatkan kedudukannya sebagai tenaga profesional sesuai dengan tuntutan masyarakat yang semakin berkembang. Dalam hal ini, guru tidak semata-mata sebagai pengajar yang melakukan transfer ilmu pengetahuan, tetapi juga sebagai pendidik yang melakukan transfer nilai-nilai sekaligus sebagai pembimbing yang memberikan pengarahan dan menuntun siswa dalam belajar. Kelengkapan 
jumlah tenaga pengajar dan kualitas dari guru tersebut akan mempengaruhi keberhasilan siswa dalam belajar yang berujung pada peningkatan mutu pendidikan. Untuk itu, guru dituntut profesional dalam menjalankan tugasnya. Undang-Undang Nomor 14 Tahun 2005 Bab IV pasal 20 (a) tentang guru dan dosen menyatakan bahwa standar prestasi kerja guru dalam melaksanakan tugas keprofesionalannya, guru berkewajiban untuk merencanakan pembelajaran, melaksanakan proses pembelajaran yang bermutu serta menilai dan mengevaluasi hasil pembelajaran.

Kemampuan profesional seorang kepala sekolah sebagai pemimpin pendidikan yaitu bertanggung jawab dalam menciptakan situasi belajar mengajar yang kondusif, sehingga guru guru dapat melaksanakan pembelajaran dengan baik dan peserta didik dapat belajar dengan tenang. Di samping itu, kepala sekolah dituntut untuk dapat bekerja sama dengan guru sebagai bawahannya. Salah satu gaya kepemimpinan yang dipandang tepat untuk kepala sekolah dalam memimpin adalah gaya kepemimpinan situasional.

Seorang guru menjadi pendidik karena adanya motivasi untuk mendidik. Bila tidak punya motivasi itu, maka ia tidak akan berhasil untuk mendidik atau jika dia mengajar karena terpaksa saja karena bukan kemauan yang berasal dari dalam diri guru.

Selain dipengaruhi oleh gaya kepemimpinan kepala sekolah dan motivasi kerja, kinerja dari guru juga dipengaruhi oleh kompetensi yang mereka miliki. Dalam UndangUndang No. 14 Tahun 2005 tentang Guru dan Dosen Pasal 10 Ayat (1) disebutkan bahwa kompetensi guru meliputi kompetensi pedagogik, kompetensi kepribadian, kompetensi sosial, dan kompetensi profesional diperoleh melalui pendidikan profesi.

\section{Kajian Literatur}

Riberu (1987:7) menyatakan gaya kepemimpinan merupakan cara-cara pemimpin membawa diri sebagai pemimpin, cara ia "berlagak" dan tampil dalam menggunakan kekuasaannya. Menurut Winardi (2000: 48), gaya kepemimpinan diartikan sebagai sebuah pendekatan yang dapat digunakan untung memahami suksesnya kepemimpinan, dalam hubungan yang mana seseorang akan memu- satkan perhatian pada apa yang dilakukan oleh pemimpin tersebut. Menurut Dharma (2004: 37), gaya kepemimpinan adalah pola tingkah laku yang ditunjukan seseorang pada saat ia mencoba mempengaruhi orang lain. Sebagaimana dikemukakan di atas, kepemimpinan situasional terdapat dua perilaku kepemimpinan yang utama, yaitu perilaku tugas dan perilaku hubungan.

Hersey dan Blanchard (2004) mengembangkan empat gaya kepemimpinan yang didasarkan kepada perilaku hubungan dan perilaku tugas tersebut. Empat gaya kepemimpinan ini adalah instruksi, konsultasi, partisipasi, serta delegasi.

Istilah motivasi berasal dari kata Latin "movere" yang berarti dorongan atau menggerakkan. Motivasi mempersoalkan bagaimana cara mengarahkan daya dan potensi agar bekerja mencapai tujuan yang ditentukan (Hasibuan, 2006:141). Vroom (1964) menjelaskan bahwa motivasi mengacu kepada suatu proses mempengaruhi pilihan-pilihan individu terhadap bermacam-macam bentuk kegiatan yang dikehendaki. Sedangkan Campbell dan Campbell (1990) mengemukakan bahwa motivasi mencakup arah atau tujuan tingkah laku, kekuatan respons, dan kegigihan tingkah laku. Purwanto (2006: 72) memberikan penjelasan bahwa motivasi mengandung tiga komponen pokok, yaitu: (1) menggerakkan, berarti menimbulkan kekuatan pada individu, memimpin seseorang untuk bertindak dengan cara tertentu, (2) mengarahkan atau menyalurkan tingkah laku agar, ia menyediakan suatu orientasi tujuan tingkah laku individu diarahkan terhadap sesuatu, dan (3) untuk menjaga atau menopang tingkah laku, lingkungan sekitar harus menguatkan (reniforce) intensitas, dorongan dan kekuatan individu.

Menurut Purwanto (2006:73), tujuan motivasi secara umum adalah untuk menggerakan atau menggugah seseorang agar timbul keinginan dan kemauannya untuk melakukan sesuatu sehingga dapat memperoleh hasil atau mencapai tujuan tertentu. Menurut Hamalik (2009: 160), tujuan motivasi adalah sesuatu yang hendak dicapai oleh suatu perbuatan yang apabila tercapai akan memuaskan individu. 
Siagian (1996:294) menyatakan bahwa motivasi kerja dipengaruhi oleh beberapa faktor, baik yang bersifat internal maupun eksternal. Yang termasuk faktor internal, meliputi: (1) persepsi seseorang mengenai diri sendiri, (2) harga diri, (3) harapan pribadi, (4) kebutuhan, (5) keinginan, (6) kepuasan kerja, dan (7) prestasi kerja yang dihasilkan. Fakor eksternal yang mempengaruhi motivasi seseorang, meliputi: (1) jenis dan sifat pekerjaan, (2) kelompok kerja dimana seseorang bergabung, (3) organisasi tempat orang bekerja, (4) situasi lingkungan kerja, dan (5) gaji.

Syah (2000:229) mengemukakan pengertian dasar kompetensi adalah kemampuan atau kecakapan. Usman (2009:1) mengeImukakan bahwa kompentensi berarti suatu hal yang menggambarkan kualifikasi atau kemampuan seseorang, baik yang kualitatif maupun yang kuantitatif. McAshan yang dikutip oleh Mulyasa (2003:38) mengemukakan bahwa kompetensi "...is a knowledge, skills, and abilities or capabilities that a person achieves, which become part of his or her being to the extent he or she can satisfactorily perform particular cognitive, affective, and psychomotor behaviors". Dalam hal ini, kompetensi diartikan sebagai pengetahuan, keterampilan, dan kemampuan yang dikuasai oleh seseorang yang telah menjadi bagian dari dirinya, sehingga ia dapat melakukan perilaku-perilaku kognitif, afektif, maupun psikomotorik dengan sebaik-baiknya. Sementara itu, Finch \& Crunkilton dalam Mulyasa, (2003:38) mengartikan kompetensi sebagai penguasaan terhadap suatu tugas, keterampilan, sikap, dan apresiasi yang diperlukan untuk menunjang keberhasilan.

Sebagai salah satu sumber daya yang penting dalam sekolah, maka guru perlu dikelola secara lebih baik untuk meningkatkan kinerja mereka. Peningkatan kinerja guru akan berpengaruh kepada peningkatan kualitas output SDM yang dihasilkan dalam proses pendidikan dan pembelajaran. Kualitas pendidikan dan lulusan sering kali dipandang tergantung kepada peran guru dalam pengelolaan komponen-komponen pengajaran yang digunakan dalam proses belajar mengajar yang menjadi tanggung jawabnya. Untuk dapat mencapai hasil belajar yang optimal ten- tunya guru harus memiliki dan menampilkan kinerja yang maksimal selama proses belajar dan mengajar dengan menyesuaikan perkembangan ilmu pengetahuan dan teknologi. Kinerja guru ini terefleksi di dalam merencanakan, melaksanakan, dan menilai proses belajar mengajar yang intesitasnya dilandasi oleh etos kerja, serta profesional guru dalam proses pembelajaran. Kepala sekolah merupakan pemimpin formal dalam lingkungan sekolah yang hendaknya memiliki pandangan dan wawasan yang luas dalam mengemban visi dan misi sekolah.

Gaya kepemimpinan situasional kepala sekolah merupakan gaya kepemimpinan yang terdiri dari empat macam yaitu instruksi, konsultasi, partisipasi, serta delegasi dan dipergunakan kepala sekolah untuk mempengaruhi guru sebagai bawahannya yang disesuaikan dengan tingkat kematangan guru agar bersedia bekerja secara efektif dan efisien guna mencapai tujuan yang ditetapkan.

Seorang guru menjadi pendidik karena adanya motivasi untuk mendidik. Bila tidak punya motivasi maka ia tidak akan berhasil untuk mendidik atau jika dia mengajar karena terpaksa saja karena tidak kemauan yang berasal dari dalam diri guru. Adanya motivasi kerja ini yang dapat menyebabkan seorang guru untuk bersemangat dalam menjalankan tugas sebagai pendidik karena terpenuhi kebutuhannya.

Selain dipengaruhi oleh gaya kepemimpinan kepala sekolah dan motivasi kerja, kinerja dari guru juga dipengaruhi oleh kompetensi yang mereka miliki. Kompetensi tersebut adalah berupa kompetensi pedagogik yaitu kemampuan mengelola pembelajaran para peserta didik. Kompetensi kepribadian merupakan kemampuan kepribadian yang mantap, berakhlak mulia, arif, serta berwibawa dan menjadi teladan bagi peserta didik.

Beberapa hipotesis yang diajukan dalam penelitian ini adalah sebagai berikut ini.

1. Terdapat pengaruh secara parsial gaya kepemimpinan kepala sekolah, motivasi kerja dan kompetensi terhadap kinerja guru SD Negeri se-Kecamatan Martapura Barat Kabupaten Banjar.

2. Terdapat pengaruh secara simultan gaya kepemimpinan kepala sekolah, motivasi kerja, dan kompetensi terhadap kinerja gu- 
ru SD Negeri se-Kecamatan Martapura Barat Kabupaten Banjar.

3. Variabel kompetensi berpengaruh dominan terhadap kinerja guru SD Negeri seKecamatan Martapura Barat Kabupaten Banjar.

\section{Metode Penelitian}

Penelitian ini termasuk penelitian eksplanatif yang menjelaskan hubungan sebabakibat dan deskriptif untuk menjelaskan hubungan tersebut. Sukardi (2009: 14) menyatakan bahwa penelitian deskriptif adalah penelitian yang berusaha menggambarkan kegiatan penelitian. Penelitian deskriptif juga disebut penelitian praeksperimen karena dalam penelitian ini dilakukan eksplorasi, menggambarkan, dengan tujuan untuk dapat menerangkan dan memprediksi terhadap suatu gejala yang berlaku atas dasar data yang diperoleh di lapangan. Nawawi (2003:64) menyatakan bahwa penelitian deskriptif yaitu penelitian yang memusatkan perhatian pada masalah atau fenomena yang bersifat aktual pada saat penelitian dilakukan, kemudian menggambarkan fakta-fakta tentang masalah yang diselidiki sebagaimana adanya diiringi dengan interprestasi yang rasional dan akurat. Sementara itu, penelitian kuantitatif menurut Sugiyono (2010:14) merupakan metode penelitian yang berlandaskan pada filsafat positivisme digunakan untuk meneliti pada populasi atau sampel tertentu, teknik pengambilan sampel pada umumnya dilakukan secara random, pengumpulan data menggunakan instrumen penelitian, analisis data kuantitatif (statistik) dengan tujuannya untuk menguji hipotesis yang telah ditetapkan.

Orang-orang, lembaga, organisasi, dan benda-benda yang menjadi sasaran penelitian merupakan anggota populasi. Anggota populasi yang terdiri atas orang orang biasa disebut subjek penelitian, tetapi kalau bukan orang disebut objek penelitian. Penelitian tentang suatu objek mungkin diteliti langsung terhadap objeknya, tetapi mungkin juga hanya dinyatakan kepada orang yang mengetahui atau bertanggung jawab terhadap objek tersebut. Orang yang diminta menjelaskan dari objek yang diteliti disebut responden (Sukmadinata, 2008:250).
Arikunto (2006:108) menyebutkan bahwa populasi adalah keseluruhan objek penelitian yang memiliki karakteristik tertentu. Berdasarkan pendapat ini, maka dapat ditentukan bahwa populasi penelitian ini adalah seluruh guru SD Negeri Gugus I se-Kecamatan Martapura Barat Kabupaten Banjar yaitu berjumlah 57 orang dan tersebar pada 6 sekolah.

Nazir (2005:271) mengungkapkan bahwa populasi adalah kumpulan dari individu dengan kualitas serta ciri-ciri yang telah ditetapkan. Menurut Usman dan Akbar (2012: 182), sampel adalah sebagian anggota populasi yang diambil dengan menggunakan teknik tertentu yang disebut dengan teknik sampling. Sementara itu, menurut Sukmadinata (2008:250), tidak semua anggota populasi adalah target diteliti. Penelitian hanya dilakukan terhadap sekelompok anggota populasi yang mewakili populasi. Kelompok kecil yang secara nyata kita teliti dan tarik kesimpulan dari padanya disebut sampel.

Mengingat jumlah populasi pada penelitian ini yang tidak terlalu banyak (kurang dari 100), maka teknik pengambilan sampel yang dipergunakan adalah sampel total (total sampling). Hal ini berpatokan berdasarkan pendapat Arikunto (2006:134) yaitu untuk sekedar ancer-ancer maka apabila subjeknya kurang dari 100, lebih baik diambil semua. Dengan demikian, dapat diperoleh sampel penelitian ini adalah sebanyak 57 guru SD Negeri Gugus I se-Kecamatan Martapura Barat Kabupaten Banjar.

Teknik analisis data yang digunakan adalah analisis regresi linear berganda. Teknik ini sangat tepat untuk mengukur seberapa besar kemampuan dari variabel bebas untuk mempengaruhi variabel berikat.

\section{Hasil Penelitian dan Pembahasan}

Gaya kepemimpinan kepala sekolah merupakan perilaku atau cara yang digunakan oleh seorang kepala sekolah untuk mempengaruhi para guru agar dapat bekerja dengan baik sesuai tujuan sekolah yang telah ditetapkan sebelumnya. Kepala sekolah sebagai pemimpin di suatu sekolah harus mengusahakan dengan maksimal agar keefektifan perilaku dan gaya kepemimpinannya dapat terwujud. Pemimpin yang efektif, dapat 
menjalankan organisasi sekolah dengan baik, pola komunikasi dapat berlangsung dengan lancar, memiliki metode dan prosedur yang jelas, dan seluruh personalia sekolah dapat diorganisasikan dengan baik untuk menjalankan tugasnya masing-masing sebagai upaya untuk mewujudkan tujuan sekolah yang telah disepakati bersama. Salah satu gaya kepemimpinan yang sering digunakan oleh kepala sekolah dalam memimpin adalah gaya kepemimpinan situasional. Gaya kepemimpinan ini lebih berfokus pada karakteristik bawahan yakni guru. Apabila gaya kepemimpinan kepala sekolah sesuai dengan tingkat kematangan guru, maka kinerja guru pasti akan meningkat.

Berdasarkan hasil penelitian analisis data secara deskriptif dapat diketahui bahwa sebagian besar gaya kepemimpinan kepala SD se-Kecamatan Martapura Barat adalah berada pada klasifikasi sedang yaitu sebanyak 78,95\%. Sebagian sangat kecil lagi gaya kepemimpinan kepala SD se-Kecamatan Martapura Barat berada pada klasifikasi tinggi yaitu sebanyak $12,28 \%$ dan rendah sebanyak $8,77 \%$. Sementara itu, sebagian besar kinerja guru SD se-Kecamatan Martapura Barat adalah berada di klasifikasi sedang yaitu sebanyak $71,93 \%$. Sebagian sangat kecil kinerja guru masih berada pada klasifikasi rendah yaitu sebanyak 21,05\%. Sedangkan sisanya sebagian sangat kecil lagi sebanyak 7,02\% berada pada klasifikasi tinggi. Kemudian, hasil perhitungan menggunakan regresi linear secara sederhana diperoleh nilai $t_{\text {hitung }}$ yaitu sebesar 2,209, sedangkan $t_{\text {tabel }}$ pada taraf signifikansi $\alpha=0,05$ dan $N=57$ yaitu sebesar 2,000. Karena nilai $t_{\text {hitung }}=2,209>t_{\text {tabel }}$ = 2,000, maka $\mathrm{H}_{\mathrm{o}}$ ditolak dan diterima $\mathrm{H}_{\mathrm{a}}$. Dengan demikian, dapat disimpulkan terdapat pengaruh gaya kepemimpinan kepala sekolah terhadap kinerja guru SD Negeri se Kecamatan Martapura Barat.

Seseorang yang memiliki motivasi yang tinggi akan lebih mudah dan cepat mendapatkan yang diinginkannya dibandingkan dengan orang yang tidak memiliki motivasi rendah. Dengan kata lain orang yang bermotivasi kerja yang tinggi maka kinerjanya juga akan tinggi dan sebaliknya. Motivasi memiliki hubungan yang erat dengan keberhasilan seseorang dan organisasi. Dengan adanya motivasi, seorang pegawai akan merasa mempunyai dorongan khusus menyelesaikan suatu pekerjaan menuju tercapainya efektivitas organisasi. Ketika pegawai memiliki motivasi untuk bekerja lebih, maka ia akan melaksanakan tugas dengan sebaik-baiknya. Sebaliknya, apabila pegawai menganggap bahwa melaksanakan pekerjaan hanya sebagai rutinitas maka mereka cenderung statis dalam bekerja. Seorang guru menjadi pendidik karena adanya motivasi untuk mendidik. Bila tidak punya motivasi maka ia tidak akan berhasil untuk mendidik atau jika dia mengajar karena terpaksa saja karena tidak kemauan yang berasal dari dalam diri guru.

Berdasarkan hasil penelitian analisis data secara deskriptif dapat diketahui bahwa sebagian besar motivasi kerja guru SD seKecamatan Martapura Barat adalah berada pada klasifikasi sedang yaitu sebanyak $66,67 \%$. Sisanya, sebagian sangat kecil lagi, motivasi kerja guru berada di klasifikasi tinggi yaitu sebanyak $17,54 \%$ dan rendah sebanyak $15,79 \%$. Sementara itu, sebagian besar kinerja guru SD se Kecamatan Martapura Barat adalah berada di klasifikasi sedang yaitu sebanyak $71,93 \%$. Sebagian sangat kecil kinerja guru masih berada pada klasifikasi rendah yaitu sebanyak $21,05 \%$. Sisanya, sebagian sangat kecil lagi sebanyak 7,02\% berada pada klasifikasi tinggi.

Kemudian, hasil perhitungan menggunakan regresi linear secara sederhana

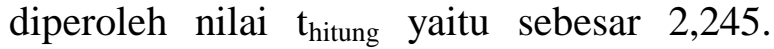
Sedangkan $\mathrm{t}$ tabel pada taraf signifikansi $\alpha=$ 0,05 dan $N=57$ yaitu sebesar 2,000. Karena nilai $t_{\text {hitung }}=2,245>t_{\text {tabel }}=2,000$, maka Ho ditolak dan diterima Ha. Dengan demikian, dapat disimpulkan terdapat pengaruh motivasi kerja terhadap kinerja guru SD Negeri se Kecamatan Martapura Barat.

Hasil penelitian ini sesuai dengan pendapat yang telah dikemukakan oleh Steers (1996:216), bahwa karyawan yang memiliki motivasi kerja tinggi sangat kecil kemungkinannya akan menampilkan kecenderungan kerja malas-malasan, absen, mogok kerja atau pindah kerja.

Kompetensi yang dimiliki oleh setiap guru akan menunjukkan kualitas guru mengajar. Kompetensi tersebut akan terwujud dalam bentuk penguasaan pengetahuan dan pro- 
fesional menjalankan fungsinya sebagai guru. Seorang guru yang profesional harus memiliki kompetensi untuk menggali informasi kependidikan dan bidang studi dari berbagai sumber, termasuk dari sumber elektronik dan pertemuan ilmiah, serta melakukan kajian atau penelitian untuk menunjang pembelajaran yang mendidik. Apabila mengacu pada empat kompetensi yang harus dikuasai guru menurut kebijakan pemerintah, yaitu dalam Undang-Undang No. 14 Tahun 2005 tentang Guru dan Dosen Pasal 10 Ayat (1) disebutkan bahwa kompetensi guru meliputi kompetensi pedagogik, kompetensi kepribadian, kompetensi sosial, dan kompetensi profesional diperoleh melalui pendidikan profesi. Oleh sebab itu, seorang guru memiliki kompetensi ditetapkan di atas akan memiliki kinerja yang lebih baik dibandingkan dengan guru yang tidak memiliki kompetensi tersebut.

Berdasarkan hasil penelitian analisis data secara deskriptif dapat diketahui bahwa sebagian sangat besar kompetensi guru SD se-Kecamatan Martapura Barat adalah berada pada klasifikasi sedang yaitu sebanyak $82,46 \%$. Sebagian kecil kompetensi guru diketahui sudah berada pada klasifikasi tinggi yaitu sebanyak $8,77 \%$, sedangkan sisanya sebagian kecil lagi yaitu sebanyak $8,77 \%$ masih berada pada klasifikasi rendah. Sementara itu, sebagian besar kinerja guru SD se-Kecamatan Martapura Barat adalah berada pada klasifikasi sedang yaitu sebanyak 71,93\%. Sebagian sangat kecil kinerja guru masih berada pada klasifikasi rendah yaitu sebanyak $21,05 \%$ dan sebanyak $7,02 \%$ berada pada klasifikasi tinggi.

Kemudian, hasil perhitungan menggunakan regresi linear secara sederhana diperoleh nilai thitung yaitu sebesar 3,514, sedangkan $t_{\text {tabel }}$ pada taraf signifikansi $\alpha=0,05$ dan $N=57$ yaitu sebesar 2,000. Karena nilai $\mathrm{t}_{\text {hitung }}=3,514>\mathrm{t}_{\text {tabel }}=2,000$, maka $\mathrm{H}_{\mathrm{o}}$ ditolak dan diterima $\mathrm{H}_{\mathrm{a}}$. Dengan demikian, dapat disimpulkan bahwa terdapat pengaruh kompetensi terhadap kinerja guru SD Negeri seKecamatan Martapura Barat.

Dapat diketahui besar koefisien pengaruh gaya kepemimpinan kepala sekolah $\left(\mathrm{X}_{1}\right)$ terhadap kinerja (Y) yaitu sebesar 0,282. Besar koefisien pengaruh motivasi kerja $\left(\mathrm{X}_{2}\right)$ terhadap kinerja (Y) adalah sebesar 0,292. Besar koefisien pengaruh kompetensi guru $\left(\mathrm{X}_{3}\right)$ terhadap kinerja $(\mathrm{Y})$ sebesar 0,415. Dari ketiga variabel yang berpengaruh terhadap kinerja guru tersebut, dapat diketahui bahwa variabel kompetensi guru memiliki pengaruh yang paling dominan terhadap kinerja guru SD Negeri se-Kecamatan Martapura Barat dibandingkan variabel lain. Implikasi penelitian ini adalah bahwa gaya kepemimpinan kepala sekolah, motivasi, dan kompetensi guru terbukti berpengaruh terhadap kinerja guru baik secara parsial maupun simultan. Hal ini berarti bahwa semakin tinggi gaya kepemimpinan kepala sekolah, motivasi dan kompetensi guru maka kinerja guru juga semakin meningkat. Motivasi berkaitan dengan tingkat usaha yang dilakukan seseorang dalam mencapai tujuan dan berkaitan dengan prestasi kerja karyawan. Oleh sebab itu, karyawan juga perlu dimotivasi serta perlu memiliki kompetensi yang sesuai untuk melakukan pekerjaannya. Memotivasi dapat dilakukan dengan berbagai cara seperti paksaan dan hukuman, imbalan, penghargaan dan pujian, dan menciptakan kompetisi, tujuan dan harapan yang jelas realistis serta mudah dicapai.

Kepemimpinan merupakan hal yang penting dalam sebuah sekolah karena hal ini akan berpengaruh pada kinerja karyawan. Gaya kepemimpinan di sekolah lebih cenderung tergantung pada keputusan pimpinan.

\section{Kesimpulan}

Berdasarkan hasil analisis data penelitian dan pembahasan, maka dapat dibuat beberapa kesimpulan sebagai berikut ini.

1. Terdapat pengaruh parsial gaya kepemimpinan kepala sekolah, motivasi kerja, dan kompetensi terhadap kinerja guru SD Negeri se-Kecamatan Martapura Barat Kabupaten Banjar.

2. Terdapat pengaruh simultan gaya kepemimpinan kepala sekolah, motivasi kerja, dan kompetensi terhadap kinerja guru SD Negeri se-Kecamatan Martapura Barat Kabupaten Banjar.

3. Variabel kompetensi memiliki pengaruh paling dominan terhadap kinerja guru SD Negeri se-Kecamatan Martapura Barat Kabupaten Banjar. 


\section{DAFTAR PUSTAKA}

Arikunto S., 2006, Prosedur Penelitian Suatu Pendekatan Praktik, Rineka Cipta, Jakarta

Campbell J.P. dan R.J., Campbell, 1990, Productivity in Organizations, Josey-Bass Publisher, San Fransisco.

Depdiknas, 2008, Penilaian Kinerja Guru, Direktorat Tenaga Kependidikan Direktorat Jenderal Peningkatan Mutu PTK, Jakarta.

Dharma Surya, 2004, Manajemen Kinerja: Falsafah, Teori, dan Penerapannya, Pustaka Jakarta:

Hamalik O., 2009, Proses Belajar Mengajar. Bumi Aksara, Bandung.

Hasibuan Malayu S.P., 2006, Manajemen Sumber Daya Manusia, Edisi Revisi, Bumi Aksara, Jakarta.

Hersey, Paul dan Kenneth Blanchard, 2004. Management of Organizational Behavior: Utilizing. Human Resources, Prentice Hall, New Jersey.

Mangkunegara, A.P., 2004, Manajemen Sumber Daya Manusia Perusahaan, Remaja Rosdakarya, Bandung.

Mulyasa E., 2003, Menjadi Kepala Sekolah Profesional dalam Konteks Menyukseskan MBS dan KBK, Remaja Rosdakarya, Bandung.

Nawawi Hadari, 2003, Metode Penelitian Sosial, Gajah Mada University Press, Yogyakarta.

Nazir M., 2005, Metode Penelitian. Bogor, Ghalia, Indonesia.
Purwanto N, 2006, Psikologi Pendidikan, Remaja Rosdakarya, Bandung.

Republik Indonesia, Undang-Undang RI Nomor 14 Tahun 2005 tentang Guru dan Dosen.

Riberu J.,1987, Dasar-dasar Kepemimpinan. Pedoman Ilmu Jaya, Jakarta.

Siagian Sondang P., 1996, Kiat Meningkatkan Produktivitas Kerja, Rineka Cipta Jakarta.

Sugiyono, 2010, Metode Penelitian Pendidikan: Pendekatan Kuantitatif-Kualitatif dan $R \& D$, Alfabeta,.Bandung.

Steers, Richard M., dkk., 1996, Motivation and Leadership at Work, McGraw-Hill International Book Company New York.

Sukardi, 2009, Metodologi Penelitian Pendidikan, Bumi Aksara, Jakarta.

Sukmadinata, 2008, Pengembangan Kurikulum: Teori dan Praktek, Alfabeta, Bandung.

Sulistiyani dan Rosidah, 2003, Manajemen Sumber Daya Manusia, Graha Ilmu, Yogyakarta.

Syah Muhibbin, 2000, Psikologi Kependidikan Suatu Pendekatan Baru. Remaja Rosdakarya, Bandung,

Usman H. dan R.P.S. Akbar, 2012, Pengantar Statistika. Bumi Aksara, Jakarta.

Usman Uzer. 2009. Menjadi Guru Profesional. Bandung: Remaja Rosdakarya.

Vroom Victor H, 1964, Work and Motivation, John Wiley and Son, New York.

Wibowo, 2007, Manajemen Kinerja, Raja Grafindo Persada, Jakarta. 